\title{
Vegetative propagation of mate from shoot cuttings induced by coppicing of selected plants
}

\section{Propagação vegetativa de erva-mate por estaquia de brotações de decepa de plantas selecionadas}

\author{
Denise Gazzana $^{1}$; Nathalia Pimentel ${ }^{1}$; Gabriele Tais Lohmann²; Luciane Grendene \\ Maculan; ; Dilson Antônio Bisogni*
}

\begin{abstract}
Highlights:
The adventitious rooting of mate cuttings is influenced by the stock plants.

The adventitious rooting is influenced by the time of shoot collection.

The adventitious rooting is influenced by the diameter of vegetative propagules.

The selection of plants, promotes the production of plantlets with morphological and genetic quality.
\end{abstract}

\begin{abstract}
Mate (Ilex paraguariensis A. St.-Hil) is an arboreal species of great economic and socio-environmental importance, which presents difficulties in the adventitious rooting process. The rhizogenic competence of vegetative propagules of mate can be attained by coppicing, but the factors that influence the success of this technique have not yet been elucidated. Therefore, the aim of this study was to evaluate the effects of the stock plant, time of shoot collection, treatment with indolebutyric acid (IBA) and diameter of vegetative propagules in the adventitious rooting of cuttings from shoots induced by coppicing of selected adult plants of mate. Shoots produced from coppiced 13SM01 and 13SM05 stock plants were collected at different times of the year to prepare single-bud cuttings. The cuttings were measured as their diameter in the central portion and treated with 0 and $3000 \mathrm{mg} \mathrm{L}^{-1}$ of IBA. After 60 days, cuttings were evaluated to determine survival and rooting percentages, number of roots, and length of the three largest roots. A completely randomized design was used in a $4 \times 2 \times 2 \times 13$ (collection times $\mathrm{x}$ stock plants $\mathrm{x}$ IBA treatment $\mathrm{x}$ diameter classes) factorial scheme with 15 replications. Competence for adventitious rooting was highest for stock plant 13SM05. Cuttings collected in November and February had the highest rooting percentages, without the need of IBA treatment. Cuttings from 13SM01 and 13SM05 with diameters smaller than $0.636 \mathrm{~cm}$ (classes 1 to 6) and smaller than $0.712 \mathrm{~cm}$ (classes 1 to 7), respectively, had the highest rooting percentages and differed significantly from cuttings with larger diameters. Thus, the results of the present study indicate that stock plants, time of shoot collection, and diameter of vegetative propagules influence adventitious rooting competence of mate cuttings from coppicing adult plants. Rooting of mate cuttings with lower rhizogenic competence is influenced by the application of $3000 \mathrm{mg} \mathrm{L}^{-1}$ of IBA.
\end{abstract}

Key words: Collection times. Cutting diameter. Ilex paraguariensis A. St.-Hil. Indolebutyric acid. Rescue of adult plants.

1 Discentes do Curso de Doutorado do Programa de Pós-Graduação em Engenharia Florestal, Departamento de Fitotecnia, Universidade Federal de Santa Maria, UFSM, Santa Maria, RS, Brasil. E-mail: denygazzana@hotmail.com; nathaliapimentel@ outlook.com;

2 Discente do Curso de Mestrado do Programa de Pós-Graduação em Engenharia Florestal, Departamento de Fitotecnia, UFSM, Santa Maria, RS, Brasil. E-mail: lucianemaculan@hotmail.com

3 Discente de Graduação em Engenharia Florestal, Departamento de Fitotecnia, UFSM, Santa Maria, RS, Brasil. E-mail: gabrielelohmann148@gmail.com

4 Prof. PhD, Centro de Ciências Rurais, Departamento de Fitotecnia, UFSM, Santa Maria, RS, Brasil. E-mail: dilson.bisognin@ufsm.br

* Author for correspondence

Received: Apr. 15, 2019 - Approved: May 26, 2020

Semina: Ciências Agrárias, Londrina, v. 41, n. 5, suplemento 1, p. 1849-1860, 2020 


\section{Resumo}

A erva-mate (Ilex paraguariensis A. St.-Hil) é uma espécie arbórea de grande importância econômica e socioambiental, que apresenta dificuldades no processo de enraizamento adventício. A competência rizogênica dos propágulos vegetativos de erva-mate pode ser obtida pelo decepa, mas os fatores que influenciam no sucesso dessa técnica ainda não foram elucidados. Assim sendo, o presente estudo objetivou avaliar a influência das características genéticas das plantas matrizes, das épocas de coleta, do tratamento com ácido indol-butírico (AIB) e do diâmetro de propágulos vegetativos no enraizamento adventício de estacas de brotações provenientes da decepa de plantas adultas selecionadas de erva-mate. Brotações produzidas a partir da decepa das plantas matrizes 13SM01 e 13SM05 foram coletadas em diferentes épocas e seccionadas em estacas de gema única. As estacas tiveram os diâmetros medidos na porção central e foram tratadas com 0 e $3000 \mathrm{mg} \mathrm{L}^{-1}$ de AIB. Aos 60 dias de cultivo, as estacas foram avaliadas quanto às porcentagens de sobrevivência e enraizamento, número de raízes e comprimento médio das três maiores raízes. O experimento foi um fatorial $4 \times 2 \times 2 \times 13$ (época de coleta $\mathrm{x}$ planta matriz $\mathrm{x}$ tratamento com AIB x classe de diâmetro das estacas) no delineamento inteiramente casualizado, com 15 repetições. A competência ao enraizamento adventício foi maior nas estacas coletadas da planta matriz 13SM05. As estacas coletadas em novembro e fevereiro apresentaram as maiores porcentagens de enraizamento, sem a necessidade de tratamento com AIB. Estacas oriundas de 13SM01 e 13SM05 com diâmetros menores que 0,636 cm (classes 1 a 6) e 0,712 cm (classes 1 a 7), respectivamente, apresentaram os maiores percentuais de enraizamento e diferiram significativamente das estacas com maiores diâmetros. Assim, os resultados do presente estudo indicam que as plantas matrizes, a época de coleta das brotações e o diâmetro dos propágulos vegetativos influenciam na competência ao enraizamento adventício de estacas de erva-mate oriundas da decepa de plantas adultas. O enraizamento de estacas com menor competência rizogênica é influenciado pela aplicação de 3000 $\mathrm{mg} \mathrm{L}^{-1}$ de AIB.

Palavras-chave: Ácido indol-3-butírico. Diâmetro das estacas. Épocas de coletas. Ilex paraguariensis A. St.-Hil. Resgate de plantas adultas.

\section{Introduction}

Mate (Ilex paraguariensis A. St.-Hil.) is a native species of Brazil with great socioeconomic and cultural importance, especially in the states of Paraná, Santa Catarina, and Rio Grande do Sul (Chechi \& Schultz, 2016). The leaves of this species have multiple therapeutic and nutraceutical uses, which has enabled, in the last decades, the by-products of mate have increasingly been in industrial processes, such as in the production of food, beverages, cosmetics, hygiene and cleaning products, and medicines (Dallabrida, Dumke, Molz, Furini, \& Giacomelli, 2016).

By-products of mate with high added value are produced in plantations with uniform growth and high productivity that depends upon high quality plantlets used for stand establishment (Santin, Wendling, Benedetti, Morandi, \& Domingos, 2015).
Plantlets with adequate quality can be obtained through vegetative propagation with a combination of desirable shoot and root development (Grossnickle \& MacDonald, 2018). The morphophysiological and genetic characteristics of the plantlets allow a rapid establishment and a successful outplanting (Davis \& Jacobs, 2005).

Cutting is the vegetative propagation technique commonly used for cloning forest species (GratieriSossella, Petry, \& Nienow, 2008), however the commercial viability of using this technique depended on the adventitious rooting competence that varies among species (Neves, Carpanezzi, Zuffellato-Ribas, \& Marenco, 2006). Mate presents low multiplication rate due to its recalcitrant behavior of cuttings rooting (Bitencourt, ZuffellatoRibas, Wendling, \& Koehler, 2009), which has restricted the mass production of plantlets of these species. The development of adventitious roots is a 
complex process which may be affected by multiple factors, including the stock plant (Geiss, Gutierrez, \& Bellini, 2009; Bisognin, Lencina, Luz, Fleig, \& Gazzana, 2018), collection time of vegetative propagules (Pimentel et al., 2019), phytohormones (Bisognin et al., 2018), and cutting diameter (Stuepp, Wendling, Xavier, \& Zuffellato-Ribas, 2018).

The rate and extent of the rooting competence has an important genetic component (Geiss et al., 2009), since the phytohormonal requirement for rhizogenic induction and reserves mobilization are genotype dependent that affect both the rooting and shooting process necessary for plantlet growth and development (Rosa, Zanandrea, Mayer, \& Bianchi, 2017). The adventitious rooting process is also affected by the ontogenetic age of the stock plant (Geiss et al., 2009; Wendling, Trueman, \& Xavier, 2014a). In most forest species, especially those that have difficulty in rooting, a juvenile gradient exists from the base of the tree (Wendling et al., 2014a). The region closest to the base of the plant is the youngest in age; thus, this region tends to produce cuttings with the greatest competence for adventitious rooting. Cuttings of mature shoots do not root or root sporadically, as the hormonal balance of the shoot differs from the hormonal balance during the juvenile state of the plant. In this case, it is necessary to use special techniques to revert to its juvenile state, such as pruning, girdling or coppicing the stock plant, to obtain satisfactory results in vegetative propagation by cuttings (Wendling et al., 2014b; Bisognin et al., 2018).

The success of cuttings adventitious rooting, even when using techniques to revert the plant's juvenile state, can be influenced by collection time of vegetative propagules. The collection time of vegetative propagules is directly related to the environmental conditions, such as temperature and photoperiod, which can directly interfere in the transpiration process of the cuttings, being able to maximize or minimize the water content and, consequently, the displacement and accumulation of endogenous auxins affecting the rhizogenic capacity of the vegetative propagules (Pizzatto et al., 2011). For easy rooting species, the collection time may be less important, while in certain species the rooting process can occur only in a specific time of the year (Zem, Weiser, Zuffellato-Ribas, \& Radomski, 2015). For mate, it is known that collection time affects the number of sprouts formed after coppicing (Stuepp, Bitencourt, Wendling, Koehler, \& Zuffellato-Ribas, 2016), and in the adventitious rooting competence of mini-cuttings (Pimentel et al., 2019). However, the collection time effects in the adventitious rooting competence of cuttings from epicormic shoots induced by coppicing is still not known.

The adventitious rooting of cuttings also can be influenced by treatment with phytohormones in the vegetative propagules. Between the phytohormones, the indolebutyric acid (IBA) is the auxin commonly used to promote rhizogenesis, because of its stability and effectiveness compared to other available auxins (Lakehal \& Bellini, 2019). Studies with cuttings from shoots induced by coppicing are controversial in terms of IBA application, in one hand showed high cutting mortality (Stuepp et al., 2015a), and in the other hand increased the percentage of rooted cuttings (Bisognin et al., 2018). These different responses to the effect of the phytohormones treatment may be associated with the evaluated genotype (Lakehal \& Bellini, 2019), and/or the cutting diameter (Rana \& Sood, 2012).

The diameter of the cuttings can be related to the quantities of nutritive reserves present in the vegetative propagules. In general, cuttings with larger diameters have the highest availability of nutrients, but in contrast, cuttings with smaller diameter may have the highest endogenous concentration of auxins, because they are close to shoot tip apices where there are produced (Dias, Franco, \& Dias, 1999). The effect of cutting diameter in the adventitious rooting competence have not been studied in mate.

Considering the importance of coppicing for the rescue of adult plants selected for quality and 
productivity of foliar mass, the aim of this study was to evaluate the effects of the stock plant, time of shoot collection, treatment with IBA and diameter of vegetative propagules in the adventitious rooting of cuttings from shoots induced by coppicing of selected adult plants of mate.

\section{Materials and Methods}

Two stock mate plants that were established in understory of the experimental area of the Department of Forestry Sciences of the Federal University of Santa Maria (UFSM) were examined in this study. Both mate plants were approximately 18 years old. The stock plants 13SM01 and 13SM05 were previously selected for adventitious rooting competence (Bisognin et al., 2018). They were coppiced to approximately $20 \mathrm{~cm}$ from the soil in January 2017. Successive collections of epicormic shoots were conducted in May 2017, November 2017, February 2018, and May 2018, to study the effect of the seasonality described by Pimentel et al. (2019). Adventitious rooting experiments were conducted in a greenhouse at the Center of Plant Breeding and Vegetative Propagation at UFSM, Santa Maria, Rio Grande do Sul, Brazil.

Immediately after collection, shoots were sectioned into cuttings with one bud, approximately $2.0 \mathrm{~cm}$ in length, with one leaf reduced to $50 \%$ of its original area. After the confection, all cuttings were measured as their diameter in the central portion, using a digital caliper. The cuttings were treated with hydroalcoholic solution $(1: 1 \mathrm{v} / \mathrm{v})$ of 0 and $3000 \mathrm{mg} \mathrm{L}^{-1}$ IBA, according to the methodology described by Bisognin et al. (2018). Cuttings were then cultivated in polyethylene trays with 100 wells, each containing equal proportions of pine barkbased commercial substrate, medium vermiculite, and coarse sand (Pimentel et al. 2017). The trays were placed in a humid chamber with a relative air humidity of approximately $85 \%$, which was achieved by automated nebulization occurring eight times a day for 1 minute.
After 60 days of cultivation in the humid chamber, the cuttings were evaluated to determine survival and rooting percentages, number of roots, and length of the three largest roots. The cuttings were considered to be rooted when they had at least one adventitious root $\geq 0.1 \mathrm{~cm}$ in length. The relations between survival and rooting percentages and its respective diameter class were examined. For this, the equations that best fit the observed data were determined, using as reference the coefficient of determination $\left(\mathrm{R}^{2}\right)$, according to the methodology used by Kielse et al. (2013) and Pimentel, Bisognin, Kielse, Lencina and Mello (2016). The number and amplitude of the cutting diameter classes of each stock plant were determined using the Sturges rule (Sturges, 1926) and the following formulas (1, 2 and 3):

$$
\begin{gathered}
\mathrm{K}=1+3,3 \times \log _{10}(\mathrm{n}) \\
\mathrm{AT}=\mathrm{X}_{\max }-\mathrm{X}_{\min } \\
\mathrm{h}=\frac{\mathrm{AT}}{\mathrm{K}}
\end{gathered}
$$

where $\mathrm{K}=$ Sturges rule; $\mathrm{n}=$ number of observations, AT $=$ total amplitude of cutting diameter, $\mathrm{X}_{\max }=$ largest diameter in $\mathrm{cm} ; \mathrm{X}_{\min }=$ smallest diameter in $\mathrm{cm}$, and $\mathrm{h}=$ amplitude of the cutting diameter classes.

The experiment was carried out as a $4 \times 2 \times 2 \times$ 13 (collection times $\mathrm{x}$ stock plants $\mathrm{x}$ IBA treatments $\mathrm{x}$ diameter classes of cuttings) factorial scheme in a completely randomized design, with 15 replications. The number of cuttings per replicate ranged from 15 to 72 , depending on the number of shoots produced by each stock plant in each collection time, for a total of 8438 cuttings over the four collections. Before running variance analyses, the assumption of normality was verified using the Shapiro-Wilk test and variance homogeneity was verified using the Bartlett test. The four collections were considered as a factor and analyzed together, as the difference between residual mean squares was less than seven for all variables (Cruz, Carneiro, \& Regazzi, 2001). 
Data were analyzed by analysis of variance and treatment means with significant differences were compared with the Scott-Knott test using a $5 \%$ error probability. Analyses were conducted using Sisvar statistical (Ferreira, 2011) and Action software (Equipe Estatcamp).

\section{Results and Discussion}

Analysis of variance showed no significant interactions $(p>0.05)$ among collection times, stock plants, IBA treatment and diameter classes of cuttings for all evaluated traits at 60 days of cultivation in the humid chamber (Table 1). There was a significant interaction between the IBA treatment of cuttings, both with the time of shoot collection and with the stock plant for all evaluated traits. The interaction between shoot collection time and stock plant was significant only for the number of roots and the length of the three largest roots. The stock plant and the diameter classes of cuttings showed significant interactions $(p<0.05)$ for the percentages of survival and rooting, and length of the three largest roots. Significant differences were observed for survival and rooting percentages of cuttings, except for rooting percentage in the IBA treatment, when the treatments were analyzed in isolation. The rooting percentage had the highest coefficient of variation, which may explain the lack of significance observed for the IBA treatment.

Table 1

Mean squares for survival and rooting percentages, number of roots (NR), and length of the three largest roots (LTR) of cuttings from two stock mate plants collected during four collection times, classified in diameter classes and treated with 0 and $3000 \mathrm{mg} \mathrm{L}^{-1}$ of indolebutyric acid (IBA) at 60 days of cultivation in a humid chamber

\begin{tabular}{lccccc}
\hline VF & DF & Survival (\%) & Rooting $(\%)$ & NR & LTR \\
\hline Collection times(A) & 3 & $3790.13^{*}$ & $2402.25^{*}$ & $8.86^{*}$ & $1.31^{*}$ \\
Stock plants (B) & 1 & $174.75^{*}$ & $1199.97^{*}$ & $17.85^{*}$ & $2.41^{*}$ \\
IBA treatment(C) & 1 & $206.26^{*}$ & $51.54^{\text {ns }}$ & $8.08^{*}$ & $0.50^{*}$ \\
Diameter classes (D) & 12 & $24766.31^{*}$ & $24842.36^{*}$ & $12.71^{\text {ns }}$ & $4.87^{\text {ns }}$ \\
A x B x C x D & 17 & $3085.34^{\text {ns }}$ & $1467.25^{\text {ns }}$ & $1.39^{\text {ns }}$ & $0.30^{\text {ns }}$ \\
C x A & 3 & $51.44^{*}$ & $63.67^{*}$ & $6.31^{*}$ & $1.38^{*}$ \\
A x B & 3 & $2.22^{\text {ns }}$ & $0.00007^{\text {ns }}$ & $2.50^{*}$ & $0.63^{*}$ \\
C x B & 1 & $190.73^{*}$ & $103.56^{*}$ & $2.19^{*}$ & $0.73^{*}$ \\
A x D & 25 & $3387.47^{*}$ & $91.02^{\text {ns }}$ & $2.80^{*}$ & $0.43^{*}$ \\
B x D & 11 & $7338.38^{*}$ & $6207.54^{*}$ & $5.23^{\text {ns }}$ & $0.87^{*}$ \\
C x D & 12 & $4219.83^{*}$ & $3093.52^{\text {ns }}$ & $1.45^{\text {ns }}$ & $0.22^{\text {ns }}$ \\
Residue & 8420 & 18.92 & 19.66 & 0.59 & 0.05 \\
\hline Mean & & 67.72 & 34.67 & 4.78 & 0.93 \\
CV $(\%)$ & & 61.99 & 112.62 & 35.63 & 19.74 \\
\hline
\end{tabular}

${ }^{*}$ Significant by F Test, $5 \%$ probability of error. ${ }^{\mathrm{ns}}$ Not significant by $\mathrm{F}$ Test, $5 \%$ probability of error.

The highest survival percentages were observed in cuttings collected in November 2017, February 2018, and May 2018 when treated with $3000 \mathrm{mg}$ $\mathrm{L}^{-1}$ of IBA (Table 2). The lowest survival percentage was observed for cuttings from the first collection
(May 2017), and IBA treatment led to increased mortality. Cuttings from the mate stock plants that were coppiced in winter of 2006 resulted in 2.50 $\%$ and $6.50 \%$ survival when treated or not with $3000 \mathrm{mg} \mathrm{L}^{-1}$ of IBA, respectively (Stuepp et al., 
2015a). These results show that the survival rates in the present study are suitable for the species, demonstrating that the conditions in the experiment favored the survival of the cuttings.

The mate cutting rooting percentage was influenced by the time of shoot collection, with the highest averages of rooting occurring in November 2017 and February 2018, with $0 \mathrm{mg} \mathrm{L}^{-1}$ of IBA (Table 2). These collections occurred during periods of high vegetative growth with long photoperiods and high temperatures (spring and summer), favoring the development of new leaves, apical buds, and meristems that maximize auxin synthesis (Ferreira, Zuffellato-Ribas, Carpanezzi, Tavares, \& Koehler, 2009). This environment provides cuttings with greater competence for adventitious rooting. Similar responses were observed for cuttings of Paulownia fortune var. mikado from coppiced adult stock plants (with or without IBA treatment), for which highest rooting percentages occurred in summer and spring (Stuepp, Wendling, Koehler, \& Zuffellato-Ribas, 2015b).

\section{Table 2}

Survival and rooting percentages, number of roots, and length of the three largest roots of mate cuttings collected during four collection times, treated with 0 and $3000 \mathrm{mg} \mathrm{L}^{-1}$ of indolebutyric acid (IBA) at 60 days of cultivation in a humid chamber

\begin{tabular}{|c|c|c|c|c|}
\hline IBA & May of 2017 & November of 2017 & February of 2018 & May of 2018 \\
\hline \multicolumn{5}{|c|}{ Survival percentage } \\
\hline $0 \mathrm{mg} \mathrm{L}^{-1}$ & $42.56 \mathrm{Ba}^{*}$ & $72.96 \mathrm{Aa}$ & $74.02 \mathrm{Aa}$ & $71.62 \mathrm{Aa}$ \\
\hline $3000 \mathrm{mg} \mathrm{L}^{-1}$ & $33.28 \mathrm{Bb}$ & $72.93 \mathrm{Aa}$ & $69.90 \mathrm{Aa}$ & $70.97 \mathrm{Aa}$ \\
\hline Mean & 37.92 & 72.94 & 71.96 & 71.29 \\
\hline \multicolumn{5}{|c|}{ Rooting percentage } \\
\hline $0 \mathrm{mg} \mathrm{L}^{-1}$ & $16.48 \mathrm{Da}$ & $41.44 \mathrm{Ba}$ & $45.71 \mathrm{Aa}$ & $21.14 \mathrm{Cb}$ \\
\hline $3000 \mathrm{mg} \mathrm{L}^{-1}$ & $17.12 \mathrm{Ca}$ & $40.63 \mathrm{Aa}$ & $43.48 \mathrm{Aa}$ & $29.27 \mathrm{Ba}$ \\
\hline Mean & 16.80 & 41.03 & 44.59 & 25.20 \\
\hline \multicolumn{5}{|c|}{ Number of roots } \\
\hline $0 \mathrm{mg} \mathrm{L}^{-1}$ & $4.49 \mathrm{Bb}$ & $3.95 \mathrm{Ba}$ & $5.27 \mathrm{Aa}$ & $3.42 \mathrm{Cb}$ \\
\hline $3000 \mathrm{mg} \mathrm{L}^{-1}$ & $6.46 \mathrm{Aa}$ & $3.99 \mathrm{Ba}$ & $5.34 \mathrm{Aa}$ & $5.78 \mathrm{Aa}$ \\
\hline Mean & 5.47 & 3.97 & 5.30 & 4.60 \\
\hline \multicolumn{5}{|c|}{ Length of the three largest roots $(\mathrm{cm})$} \\
\hline $0 \mathrm{mg} \mathrm{L}^{-1}$ & $0.70 \mathrm{Cb}$ & $0.90 \mathrm{Ba}$ & $1.09 \mathrm{Aa}$ & $0.52 \mathrm{Db}$ \\
\hline $3000 \mathrm{mg} \mathrm{L}^{-1}$ & $1.00 \mathrm{Aa}$ & $0.90 \mathrm{Aa}$ & $0.99 \mathrm{Ab}$ & $0.99 \mathrm{Aa}$ \\
\hline Mean & 0.85 & 0.90 & 1.04 & 0.75 \\
\hline
\end{tabular}

*Values followed by the same letter, capital letter on the horizontal and lowercase letter vertically; do not differ by Scott-Knott's test at $5 \%$ error probability.

There was an increase in the number of roots and length of the three largest roots observed in cuttings collected in May 2017 and May 2018 and treated with $3000 \mathrm{mg} \mathrm{L}^{-1}$ of IBA (Table 2). These collections were conducted when the plants began the resting process of vegetative growth that occurs in autumn and winter, resulting in lower concentrations of endogenous auxins (Fachinello, Hoffmann, Nachtgal, Kersten, \& Fortes, 1995). This could explain the increase in rooting percentage, number of roots and length of the three 
largest roots when $3000 \mathrm{mg} \mathrm{L}^{-1}$ of IBA was applied. These results are in agreement with those obtained from Langerstroemia indica L. cuttings, for which the number of roots increased by up to $47 \%$ when treated with $3000 \mathrm{mg} \mathrm{L}^{-1}$ of IBA (D. M. L. Lima, Klein, Salla, Moura, \& Danner, 2016). The application of 3000 $\mathrm{mg} \mathrm{L}^{-1}$ of IBA also promoted adventitious rooting of cuttings collected from different positions in the same stock plants used in the present study (Bisognin et al., 2018).

In this study, cuttings from the 13SM05 stock plant (with both 0 and $3000 \mathrm{mg} \mathrm{L}^{-1}$ of IBA) had higher rooting percentages, numbers of roots, and lengths of the three largest roots than cuttings from the 13SM01 stock plant (Table 3). In a previous experiment, the 13SM05 stock plant had higher daily rooting increments for cuttings from shoots produced below the girdling and in three different trunk positions than for cuttings from the 13SM01 stock plant (Bisognin et al., 2018). Variation in rizogeniccompetence is expected due to the differences between genotypes in ability to convert IBA to indole 3-acetic acid (IAA), which controls a plethora of developmental programs in plants, including adventitious root formation (Lakehal \& Bellini, 2019). In the present study, the treatment with $3000 \mathrm{mg} \mathrm{L}^{-1}$ IBA increased the rooting percentage of 13SM01 cuttings and in the 13SM05 stock plant increased the number of roots and the length of the three largest roots (Table 3). Similar results were observed for Vitis vinifera $\times$ $V$. rotundifolia cuttings, for which IBA application stimulated the development of a greater number, length, and fresh weight of roots (Bettoni et al., 2014), which allows the production of plantlets with suitable morphophysiological quality and, consequently, greater survival when planted in the field.

Table 3

Survival and rooting percentages, number of roots, and length of the three largest roots of cuttings of two stock mate plants treated with 0 and $3000 \mathrm{mg} \mathrm{L}^{-1}$ of indolebutyric acid (IBA) at 60 days of cultivation in the humid chamber

\begin{tabular}{lcc}
\hline IBA & $13 \mathrm{SM} 01$ & $13 \mathrm{SM} 05$ \\
$0 \mathrm{mg} \mathrm{L}{ }^{-1}$ & Survival percentage & $73.90 \mathrm{Aa}$ \\
$3000 \mathrm{mg} \mathrm{L}^{-1}$ & $65.79 \mathrm{Ba}^{*}$ & $67.85 \mathrm{Ab}$ \\
Mean & $66.16 \mathrm{Aa}$ & 70.87 \\
& 65.97 & $39.18 \mathrm{Aa}$ \\
$0 \mathrm{mg} \mathrm{L}^{-1}$ & Rooting percentage & $38.12 \mathrm{Aa}$ \\
$3000 \mathrm{mg} \mathrm{L}^{-1}$ & $27.73 \mathrm{Bb}$ & 38.65 \\
Mean & $32.15 \mathrm{Ba}$ & $4.69 \mathrm{Ab}$ \\
& 29.94 & $5.61 \mathrm{Aa}$ \\
$0 \mathrm{mg} \mathrm{L}$ & Number of roots & 5.15 \\
$3000 \mathrm{mg} \mathrm{L}^{-1}$ & $3.99 \mathrm{Ba}$ & \\
Mean & $4.30 \mathrm{Ba}$ & $0.94 \mathrm{Ab}$ \\
$0 \mathrm{mg} \mathrm{L}$ & 4.14 & $1.05 \mathrm{Aa}$ \\
$3000 \mathrm{mg} \mathrm{L}^{-1}$ & Length of the three largest roots (cm) & 0.99 \\
Mean & $0.79 \mathrm{Ba}$ & $0.84 \mathrm{Ba}$ \\
\hline
\end{tabular}

*Values followed by the same letter, capital letter on the horizontal and lowercase letter vertically; do not differ by Scott-Knott's test at $5 \%$ error probability. 
Diameters of mate cuttings ranged from 0.054 to $1.316 \mathrm{~cm}$ for stock plant 13SM01 and 0.075 to 1.261 $\mathrm{cm}$ for stock plant 13SM05. Cutting diameters were separated into 13 diameter classes using the Sturges rule (Sturges, 1926), with intervals of 0.097 and $0.091 \mathrm{~cm}$ for 13SM01 and 13SM05, respectively (Figure 1). Mate cuttings of 13SM01 (Figures $1 \mathrm{~A}$ and $1 \mathrm{C}$ ) and 13SM05 (Figures 1B and 1D) showed a negative relationship between diameter class and both survival (Figures 1A and 1B) and rooting percentage (Figures $1 \mathrm{C}$ and $1 \mathrm{D}$ ) at 60 days of cultivation in the humid chamber. Cuttings with diameters equal or greater than 1.024 and 0.985 (which correspond to diameter class 11) showed 100 $\%$ mortality for 13SM01 and 13SM05, respectively. In contrast, cuttings in smaller diameter classes (1 to 10) had the highest survival rates in the humid chamber for both stock plants (Figures 1A and 1B). This could be related to cuttings with smaller diameters are less susceptible to dehydration because less surface area is exposed to the environment and less water is needed to supply living tissues (R. L. S. Lima, Siqueira, Weber, \& Cazetta, 2006).
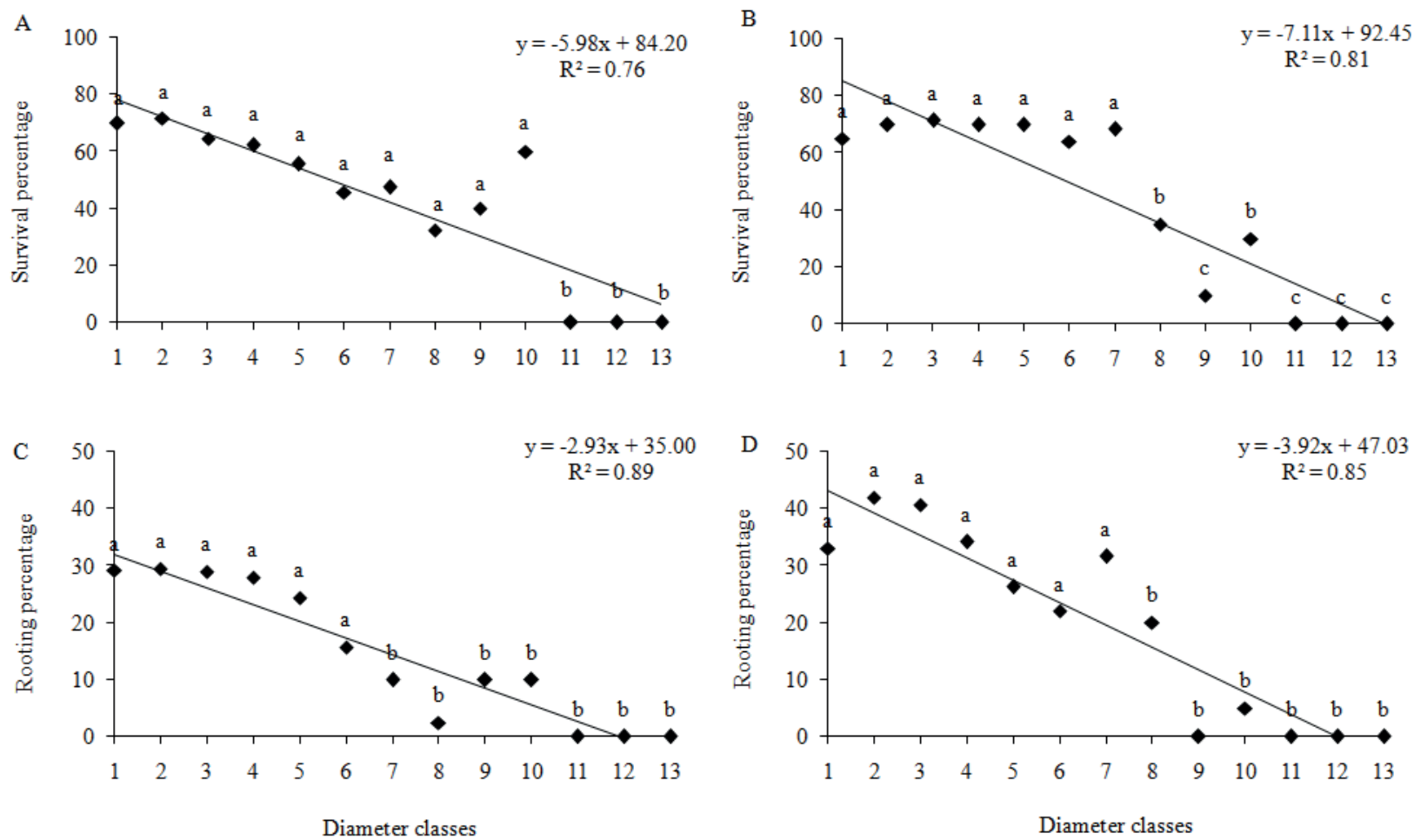

Figure 1. Survival percentage (A and B) and rooting percentage $(C$ and $D)$ of different diameter classes of cuttings of stock mate plants 13SM01 (A and C) and 13SM05 (B and D) at 60 days of cultivation in a humid chamber. Values followed by the same letter do not significantly differ from each other according to the Scott-Knott's test at 5\% error probability. Diameter classes $(\mathrm{cm})$ of cuttings from stock plant $13 \mathrm{SM} 01: 1=0.054 \quad-0.151 ; 2=0.151 \quad-0.248 ; 3=0.248$ $-0.345 ; 4=0.345 \quad-0.442 ; 5=0.442 \quad-0.539 ; 6=0.539 \quad-0.636 ; 7=0.636 \quad-0.733 ; 8=0.733 \quad-0.83 ; 9=0.83 \quad-0.927$; $10=0.927 \vdash 1.024 ; 11=1.024 \vdash 1.121 ; 12=1.121 \quad-1.218 ; 13=1.218 \mapsto 1.316$. Diameter classes $(\mathrm{cm})$ of cuttings from stock plant 13SM05: $1=0.075 \quad-0.166 ; 2=0.166 \quad-0.257 ; 3=0.257 \quad-0.348 ; 4=0.348 \quad 0.439 ; 5=0.439+0.53$; $6=0.53 \vdash 0.621 ; 7=0.621 \vdash 0.712 ; 8=0.712 \vdash 0.803 ; 9=0.803 \vdash 0.894 ; 10=0.894 \vdash 0.985 ; 11=0.985 \vdash 1.076 ; 12=$ 1.076 - $1.167 ; 13=1.167 \mapsto 1.261$. 
The results of this study show that there is a diameter limit for single-budded cuttings from shoots of coppicing that provide higher rooting percentages. Cuttings from 13SM01 and 13SM05 with diameters smaller than 0.636 (classes 1 to 6) and smaller than $0.712 \mathrm{~cm}$ (classes 1 to 7 ) had the highest rooting percentages and differed significantly from cuttings with larger diameters (Figures 1C and 1D). Therefore, rooting competence decreases with the increase in the diameter of single-budded mate cuttings. These results are in agreement with the literature, because the formation of adventitious roots is known to be related to the diameter of the vegetative propagulein woody species (Fachinello et al., 1995; Stuepp et al., 2018). For Populus tremula $\times P$. tremuloides, cuttings with smaller diameters also had the highest rooting percentages (Stenvall, Haapala, \& Pulkkinen, 2006). These results can be explained by the fact that less lignified tissues probably have lower levels of peroxidases and indoleacetic acid (IAA) oxidase, which are both involved in the degradation of IAA in inactive conjugates (Pacheco \& Franco, 2008). This suggests that cuttings with smaller diameters have higher endogenous concentrations of auxins (Dias et al., 1999), which is associated with lower concentrations of enzymes that negatively affect adventitious rooting competence.

Besides the effect of the diameter, the stock plant and time of shoot collection also influenced adventitious rooting competence of mate cuttings from coppicing. Cuttings collected in November 2017 and February 2018 had the highest rooting percentages, without the need of IBA treatment. Competence for adventitious rooting was highest for stock plant 13SM05. Overall, several factors limited vegetative propagation of mate, but the results clearly show that the stock plant selection, an adequate collection time and the selection of shoots that result in cuttings with suitable diameter are necessary to maximize the rescue of adult mate plants and the plantlet production process. These strategies promote the establishment of new stands with both the morphophysiological and genetic characteristics that result in high productivity and the specific quality necessary to supply the raw material demand for manufacturing the various products derived from mate.

\section{Conclusions}

Stock plants, time of shoot collection, and diameter of vegetative propagules influence adventitious rooting competence of mate cuttings from coppicing adult plants. Rooting of mate cuttings with lower rhizogenic competence is influenced by the application of $3000 \mathrm{mg} \mathrm{L}^{-1}$ of IBA.

\section{Acknowledgments}

The research was partially financed by the Brazilian Federal Agencies "Conselho Nacional de Desenvolvimento Científico e Tecnológico"(CNPq), Brazil, and "Coordenação de Aperfeiçoamento de Pessoal de Nível Superior" (CAPES), BrazilFinance code 001.

\section{References}

Bettoni, J. C., Gardin, J. P. P., Feldberg, N. P., Schumacher, R., Souza, J. A., \& Furlan, C. (2014). O uso de AIB melhora a qualidade de raízes em estacas herbáceas de porta-enxertos de videira. Evidência, 14(1), 4756. doi: $10.13140 / 2.1 .1428 .2884$

Bisognin, D. A., Lencina, K. H., Luz, L. V., Fleig, F. D., \& Gazzana, D. (2018). Adventitious rooting competence and rescue of adult mate plants by cuttings. Revista Árvore, 42(3), 1-10. doi: 10.1590/1806-90882018000300012

Bitencourt, J., Zuffellato-Ribas, K. C., Wendling, I., \& Koehler, H. S. (2009). Enraizamento de estacas de erva-mate (Ilex paraguariensis A. St.-Hill.) provenientes de brotações rejuvenescidas. Revista Brasileira de Plantas Medicinais, 11(3), 277-281. doi: 10.1590/S1516-05722009000300008

Chechi, L., \& Schultz, G. (2016). A produção de ervamate: um estudo da dinâmica produtiva nos estados do sul do Brasil. Enciclopédia Biosfera, 13(23), 1626. doi: 10.18677/Enciclopedia_Biosfera_2016_002 
Cruz, C. D., Carneiro, P. C. S., \& Regazzi, A. J. (2001). Modelos biométricos aplicados ao melhoramento genético (3nd ed.). Viçosa, MG: Universidade Federal de Viçosa.

Dallabrida, V. R., Dumke, C. I., Molz, S., Furini, V., \& Giacomelli, M. B. O. (2016). Com erva-mate não se faz só chimarrão! Situação atual e perspectivas de inovação no setor ervateiro do planalto norte catarinense. Desenvolvimento Regional em Debate, 6(2), 247-273. doi: 10.24302/drd.v6i2.1225

Davis, A. S., \& Jacobs, D. F. (2005). Quantifying root system quality of nursery seedlings and relationship to outplanting performance. New Forests, 30(2-3), 295-311. doi: 10.1007/s11056-005-7480-y

Dias, R. M. S. L., Franco, E. T. H., \& Dias, C. A. (1999). Enraizamento de estacas de diferentes diâmetros em Platanus acerifolia (Aiton) Willdenow. Ciência Florestal, 9(2), 127-136. doi: 1010.5902/1980 5098390

Fachinello, J. C., Hoffmann, A., Nachtgal, J. C., Kersten, E., \& Fortes, G. R. L. (1995). Propagação de plantas frutiferas de clima temperado. Pelotas, RS: UFPEL Editora Universitária.

Ferreira, B. G. A., Zuffellato-Ribas, K. C., Carpanezzi, A. A., Tavares, F. R., \& Koehler, H. S. (2009). Metodologias de aplicação de AIB no enraizamento de estacas semilenhosas de Sapium glandulatum (Vell.) Pax. Revista Brasileira de Plantas Medicinais, 11(2), 196-201. doi: 10.1590/S1516-05722009 000200014

Ferreira,D.F.(2011). Sisvar: a computerstatistical analysis system. Ciência e Agrotecnologia, 35(6),1039-1042. doi: $10.1590 /$ S1413-70542011000600001

Geiss, G., Gutierrez, L., \& Bellini, C. (2009). Adventitious root formation: new insights and perspectives. Annual Plant Reviews, 37(1), 127-156. doi: 10.1002/9781119312994.apr0400

Gratieri-Sossella, A., Petry, C., \& Nienow, A. A. (2008). Propagação da corticeira do banhado (Erythrina crista-galli L.) (Fabaceae) pelo processo de estaquia. Revista Árvore, 32(1), 163-171. doi: 10.1590/S0 100-67622008000100018.

Grossnickle, S. C., \& MacDonald, J. E. (2018). Why seedlings grow: influence of plant attributes. New Forests, 49(1), 1-34. doi: 10.1007/s11056-017-9606-4

Kielse, P., Bisognin, D. A., Heberle, M., Fleig, F. D., Xavier A., \& Rauber, M. A. (2013). Propagação vegetativa de Cordia trichotoma (Vell.) Arrab. ex Steudel por estaquia radicular. Revista Árvore, 37(1), 59-66. doi: 10.1590/S0100-67622013000100007
Lakehal, A., \& Bellini, C. (2019). Control of adventitious root formation: insights into synergistic and antagonistic hormonal interactions. Physiologia Plantarum, 165(1), 90-100. doi: 10.1111/ppl.12823

Lima, D. M. L., Klein, A. W., Salla, V. P., Moura, A. P. C., \& Danner, M. A. (2016). Ácido indolbutírico no enraizamento de estacas de Langerstroemia indica em diferentes substratos. Pesquisa Florestal Brasileira, 36(88), 549-554. doi: 10.4336/2016. pfb.36.88.1022

Lima, R. L. S., Siqueira, D. L., Weber, O. B., \& Cazetta, J. O. (2006). Comprimento de estacas e parte do ramo na formação de mudas de aceroleira. Revista Brasileira de Fruticultura, 28(1), 83-86. doi: 10.1590/S0100-29452006000100024

Neves, T. S., Carpanezzi, A. A., Zuffellato-Ribas, K. C., \& Marenco, R. A. (2006). Enraizamento de corticeira-da serra em função do tipo de estaca e variações sazonais. Pesquisa Agropecuária Brasileira, 41(12), 1699-1705. doi: 10.1590/S0100204X2006001200003

Pacheco, J. P., \& Franco, E. T. H. (2008). Ácido indolbutírico em diferentes diâmetros na estaquia de Luehea divaricata. Revista Ciência Rural, 38(6), 1624-1629. doi: 10.1590/S010384782008000600020

Pimentel, N., Bisognin, D. A., Kielse, P., Lencina, K. H., \& Mello, U. S. (2016). Shoot segment and substrate composition in rooting of juvenile ipe-roxo mini-cuttings. Ciência Rural, 46(6), 996-1002. doi: $10.1590 / 0103-8478 \mathrm{cr} 20140361$

Pimentel, N., Lencina, K. H., Kielse, P., Pedroso, M. F., Somavilla, T. M., \& Bisognin, D. A. (2017). Morphophysiological quality of yerba mate plantlets produced by mini-cuttings. Semina: Ciências Agrárias, 38(6), 3515-3528. doi: 10.5433/1679-0359.2017v38n6p3515

Pimentel, N., Lencina, K. H., Kielse, P., Rodrigues, M. B., Somavilla, T. M., \& Bisognin, D. A. (2019). Produtividade de minicepas e enraizamento de miniestacas de clones de erva-mate (Ilex paraguariensis A. St.-Hil.). Revista Ciência Florestal, 29(2), 559-570. doi: 10.5902/1980509827009

Pizzatto, M., Wagner, A., Jr., Luckmann, D., Pirola, K., Cassol, D. A., \& Mazaro, S. M. (2011). Influência do uso de AIB, época de coleta e tamanho de estaca na propagação vegetativa de hibisco por estaquia. Revista Ceres, 58(4), 487-492. doi: 10.1590/S0034737X2011000400013 
Rana, R. S., \& Sood, K. K. (2012). Effect of cutting diameter and hormonal application on the propagation of Ficus roxburghii Wall. through branch cuttings. Annals of Forest Research, 55(1), 69-84.

Rosa, G. G. da, Zanandrea, I., Mayer, N. A., \& Bianchi, V. J. (2017). Propagação de porta-enxerto de Prunus spp. por estaquia: efeito do genótipo, do estádio de desenvolvimento do ramo e tipo de estaca. Revista Ceres, 64(1), 90-97. doi: 10.1590/0034737X201764010013

Santin, D., Wendling, I., Benedetti, E. L., Morandi, D., \& Domingos, D. M. (2015). Sobrevivência, crescimento e produtividade de plantas de erva-mate produzidas por miniestacas juvenis e por sementes. Revista Ciência Florestal, 25(3), 571-579. doi: 10.5902/1980509819608

Stenvall, N., Haapala, T., \& Pulkkinen, P. (2006). The role of a root cutting's diameter and location on the regeneration ability of hybrid aspen. Forest Ecology and Management, 37(1), 150-155. doi: 1010.1016/ j.foreco.2006.09.040

Stuepp, C. A., Bitencourt, J., Wendling, I., Koehler, H. S., \& Zuffellato-Ribas, K. C. (2015a). Propagação de erva-mate utilizando brotações de anelamento e decepa em matrizes de duas idades. Cerne, 21(4), 519-526. doi: 10.1590/01047760201521041864

Stuepp, C. A., Bitencourt, J., Wendling, I., Koehler, H. S., \& Zuffellato-Ribas, K. C. (2016). Indução de brotações epicórmicas por meio de anelamento e decepa em erva-mate. Revista Ciência Florestal, 26(3), 1009-1022. doi: 10.5902/19805098242
Stuepp, C. A., Wendling, I., Koehler, H. S., \& ZuffellatoRibas, K. C. (2015b). Estaquia de árvores adultas de Paulownia fortunei var. Mikado a partir de brotações epicórmicas de decepa. Revista Ciência Florestal, 25(3), 667-677. doi: 10.5902/1980509819617

Stuepp, C. A., Wendling, I., Xavier, A., \& ZuffellatoRibas, K. C. (2018). Vegetative propagation and application of clonal forestry in Brazilian native tree species. Pesquisa Agropecuária Brasileira, 3(9), $985-$ 1002. doi: 10.1590/S0100-204X2018000900002

Sturges, H. A. (1926). The choice of a class interval. Journal of the American Statistical Association, 21(153), 65-66.

Wendling, I., Trueman, S. J., \& Xavier, A. (2014a). Maturation and related aspects in clonal forestry-Part I: concepts, regulation and consequences of phase change. New Forests, 45(1), 1-23. doi: 10.1007/ s11056-014-9421-0

Wendling, I., Trueman, S. J., \& Xavier, A. (2014b). Maturation and related aspects in clonal forestryPart II: reinvigoration, rejuvenation and juvenility maintenance. New Forests, 45(1), 1-14. doi: 10.1007/ s11056-014-9415-y

Zem, L. M., Weiser, A. H., Zuffellato-Ribas, K. C., \& Radomski, M. I. (2015). Estaquia caulinar herbácea e semilenhosa de Drimys brasiliensis. Revista Ciência Agronômica, 46(2), 396-403. doi: 10.5935/18066690.20150019 
